\title{
Prediction of Preeclampsia: Role of Antiangiogenic and Proangiogenic Biomarkers
}

\author{
${ }^{1}$ Ruchika Garg, ${ }^{2}$ Priyankur Roy, ${ }^{3}$ Prabhat Agrawal, ${ }^{4} S$ Shanthakumari
}

\begin{abstract}
The pathogenesis of preeclampsia (PE) is unknown, but recent studies have revealed that placenta is the place of origin of this disorder, and widespread maternal endothelial dysfunction is the charactertstic feature of the disease. Some biochemical molecules that are involved in the pathogenesis of the disease have recently been identified, which may help in early identification of patients at risk and help in providing proper prenatal care. Several promising biomarkers have been proposed, alone or in combination. Maternal serum concentrations of these biomarkers either increase or decrease in PE during gestation. This review focuses on the various biomarkers available and their utility in prediction and diagnosis of PE.
\end{abstract}

Keywords: Antiangiogenic, Endothelial, Placenta.

How to cite this article: Garg R, Roy P,Agrawal P, Shanthakumari S. Prediction of Preeclampsia: Role of Antiangiogenic and Proangiogenic Biomarkers. J South Asian Feder Obst Gynae 2017;9(1): 47-52.

Source of support: Nil

Conflict of interest: None

Date of received: 25 October 2016

Date of acceptance: 10 December 2016

Date of publication: January 2017

\section{INTRODUCTION}

Preeclampsia (PE) is an important cause of maternal and perinatal morbidity and mortality. About 2 to $8 \%$ of pregnancies are affected by PE. ${ }^{1}$ More than 50,000 maternal deaths annually happen due to PE worldwide. ${ }^{2,3}$

Preeclampsia can be classified as early-onset PE occurring before 34 weeks of gestational age and

\footnotetext{
${ }^{1}$ Assistant Professor, ${ }^{2}$ Fellow, ${ }^{3}$ Associate Professor, ${ }^{4}$ Consultant ${ }^{1}$ Department of Obstetrics and Gynecology, Sarojini Naidu Medical College, Agra, Uttar Pradesh, India

${ }^{2}$ Department of Obstetrics and Gynecology, JSS Medical College and Hospital, Mysuru, Karnataka, India

${ }^{3}$ Department of Medicine, Sarojini Naidu Medical College, Agra Uttar Pradesh, India

${ }^{4}$ Department of Obstetrics and Gynecology, Yasoda Hospital Hyderabad, India

Corresponding Author: Ruchika Garg, Assistant Professor Department of Obstetrics and Gynecology, Sarojini Naidu Medical College, Agra, Uttar Pradesh, India, e-mail: ruchikagargagra@ gmail.com
}

late-onset PE that develops after 34 weeks of gestational age. Early-onset PE is commonly associated with fetal growth restriction, abnormal uterine and umbilical artery Doppler waveforms, and adverse maternal and perinatal outcomes, whereas a mild form of maternal and fetal involvement with usually a favorable perinatal outcome is seen in late-onset PE. ${ }^{4-6}$ About onethird of maternal mortality is caused by PE in developing countries due to poor health care facilities. ${ }^{7}$ In India, the incidence of PE and eclampsia is around $4.6 \%,{ }^{8}$ and the neonatal mortality rate is around 43 per 1,000 live births. ${ }^{9}$

For prediction of $\mathrm{PE}$, numerous tests have been described either singly or in combination; the sensitivity and specificity of these tests need evaluation.

\section{PATHOGENESIS}

The etiology of PE is unknown. Evidence suggests that the presence of a placenta but not necessarily a fetus is required for the development of this disorder. ${ }^{10}$ Several mechanisms have been implicated in the pathogenesis of PE, including endothelial dysfunction, ${ }^{11}$ inflammatory pathway, ${ }_{1}^{12}$ oxidative stress, ${ }_{1}^{13}$ and the renin-angiotensin system. ${ }^{14}$

Preeclampsia has been considered as a two-stage disease in which abnormal placentation precedes endothelial dysfunction. ${ }^{15,16}$ In normal placental development, the cytotrophoblasts invade the maternal spiral arterioles and transform them from small-caliber resistance vessels to high-caliber conduit vessels. The beginning of this initial event has occurred around 10 to 12 weeks and is completed by 18 to 20 weeks of gestation. During this vascular invasion, the cytotrophoblasts differentiate from epithelial phenotype to an endothelial phenotype, a process known as pseudovasculogenesis. During this process, these make a direct contact with maternal blood. This process involves a considerable number of transcription factors, growth factors, and cytokines like VE-cadherin and alpha(v)beta-3 integrins. ${ }^{17}$ During PE, the invasive cytotrophoblasts fail to transform epithelial phenotype into endothelial phenotype along with shallow invasion of the spiral arteriole, which leads to defective uteroplacental circulation and worsening placental perfusion causing placental ischemia and hypoxia. ${ }^{18}$ All 
these directly or indirectly damage endothelial cell function. ${ }^{19}$ Generalized endothelial dysfunction with systemic inflammatory response is thought to be the final common pathway that leads to the maternal signs of PE with de novo hypertension and proteinuria in the second half of pregnancy. ${ }^{20}$

As PE is very common in pregnancy and carries a high maternal and perinatal morbidity and mortality, a number of methods are tried to predict the development of PE so that we can identify these women early and appropriate measures can be taken for safe pregnancy outcomes.

Prediction is basically dependent on clinical tests, such as blood pressure measurement during the second trimester or 24-hour ambulatory blood pressure monitoring, angiotensin infusion test, roll-over test, and some more, but these lack sensitivity and specificity. ${ }^{21}$

\section{ANGIOGENIC FACTORS}

Circulating factors that regulate blood vessel formation and health are referred to as angiogenic factors. Some novel soluble angiogenic factors are identified that are related to the pathogenesis of the disease. ${ }^{22}$ Angiogenic factors are thought to be important in the regulation of placental vascular development. These factors include circulating antiangiogenic proteins, such as soluble fms-like tyrosine kinase-1 (sflt-1) and soluble endoglin (sEng) and proangiogenic protein, such as placental growth factor (PlGF) and vascular endothelial growth factor (VEGF). Their receptors, fms-like tyrosine kinase or Flt-1, also known as vascular endothelial growth factor receptor-1 (VEGFR-1), VEGFR-2, Tie-1, and Tie-2, are essential for normal placental vascular development. A strong association between altered circulating angiogenic factors and PE has been demonstrated by several studies. The higher relative concentration of antiangiogenic factors is believed to trigger vascular endothelial cell injury in the liver, kidney, brain as well as in the placenta. ${ }^{5,15,23}$ Some of the factors are described here.

\section{Endoglin}

Endoglin, an antiangiogenic protein, has been implicated in the pathogenesis of PE. It is a $180-\mathrm{kDa}$, homodimeric, type I membrane glycoprotein located on cell surfaces. It is also commonly referred to as CD105, END, FLJ41744, HHT1, ORW, and ORW1. It is a part of the transforming growth factor (TGF) beta receptor complex expressed at high levels on vascular endothelial cells and functions as an antiangiogenic factor by binding TGFb- 1 and TGFb-3 proteins that are important for angiogenesis. ${ }^{24}$ Several studies have demonstrated that endoglin is expressed in human first trimester decidua cells and is highly upregulated in the syncytiotrophoblast of women with $\mathrm{PE}^{25,26}$ and concentration of its soluble form is increased in the circulation of preeclamptic women. This soluble form of endoglin (sEng) is produced by the proteolytic cleaving action of matrix metalloproteinase (MMP)-14 in extracellular domain. ${ }^{24,27}$ It acts by antagonizing an angiogenic and vasodilator molecule known as TGFb-1, which is important in angiogenesis and also maintains the health of the blood vessels. Due to this, cells lining the blood vessels begin to sicken and die, blood pressure increases, and blood vessels leak protein into the tissues and urine. ${ }^{28}$ It is an important protein for tumor growth, survival, and metastasis of cancer cells to other locations in the body.

In human pregnancy, alterations in serum sEng antedate clinical symptoms of PE by several months before the onset of disease. ${ }^{29}$ Because high levels of serum sEng are released into the human circulation prior to the clinical manifestations of $\mathrm{PE}$, this glycoprotein has been proposed recently as a serum diagnostic biomarker for PE. ${ }^{30}$ Levine et $\mathrm{al}^{29}$ evaluated the potential of sEng in combination with other pro- and antiangiogenic factors like PlGF, sFlt1 for the prediction of PE. The study implied that the sFlt1:PlGF ratio and more specifically (sFlt-1+sEng):PlGF is a stronger predictor of $\mathrm{PE}$ in comparison to individual markers. ${ }^{31}$

\section{Vascular Endothelial Growth Factor and Placental Growth Factor}

Among the various angiogenic factors expressed by the placenta, VEGF and PlGF play a very important role. $^{32}$ The VEGFs are a family of structurally related dimeric proteins whose members include VEGF-A, VEGF-B, VEGF-C, VEGF-D, and PlGF. The VEGF plays an important role to promote sustenance, migration, and differentiation of endothelial cells and also maintain the vascular permeability; VEGF interacts with VEGFR-2 and VEGFR-1 on the placental endothelial cells. ${ }^{33}$ Several studies have reported that serum concentration of VEGF is reduced in preeclamptic patients. That is why the activity of sFlt-1 (a soluble form of VEGF receptor-1 or sVEGFR-1) is upregulated in preeclamptic conditions. ${ }^{34}$ Increased levels of free serum sFlt1 bind with both VEGF and PlGF, thereby neutralizing them, and subsequently their levels in circulation are reduced. ${ }^{34}$ There is also decreased production of VEGF by circulating $\mathrm{T}$ and natural killer cells in PE; it also plays a role in endothelial dysfunction, which is characteristic of the maternal syndrome of the disease. ${ }^{35}$ Although VEGF has been studied as a promising marker for the prediction of $\mathrm{PE}^{36}$ it could not be detected by many available enzyme-linked immunosorbent assay (ELISA) kits because its circulatory levels are very low. ${ }^{37}$ To overcome this limitation, highly sensitive ELISA kits can be used. ${ }^{37}$ 
One of the most important members of VEGF family is PlGF. It also has an important role in angiogenesis and placental vasculature. ${ }^{38}$ Placental trophoblasts are the major source of PlGF; PlGF-1, PlGF-2, PlGF-3, and PlGF-4 are the different isoforms of PlGF; PlGF binds only to VEGFR-1. ${ }^{39}$ In women who are destined to develop PE, the splice variant of VEGFR-1, the sFlt-1, readily neutralizes the PlGF, hence, its level in the serum reduces. ${ }^{32,36,38}$ Various studies have demonstrated that maternal serum levels of PlGF are lower in both early- and late-onset PE. ${ }^{38,40}$ Various studies suggest that the best method for prediction of PE is PlGF:sFlt-1 ratio. ${ }^{38}$

\section{Soluble FMS-like Tyrosine Kinase 1}

It is an antiangiogenic soluble form of type 1 VEGF receptor. It results from alternative splicing of Flt-1 receptor messenger ribonucleic acid, which is an endothelial receptor for VEGF and PlGF; sFlt-1 consists of an extracellular ligand binding domain of Flt-1, but lacks the transmembrane and intracellular signaling domain. This secretory form circulates freely in the serum where it binds and neutralizes the VEGF and PlGF. ${ }^{41}$ When compared with control subjects, in the women who developed PE, a significant rise in serum levels of sFlt-1 was shown by several studies. ${ }^{34}$ The sFlt-1-specific ELISA kits are used for estimation of its serum levels. ${ }^{34}$ Baumann et $\mathrm{al}^{42}$ reported the predictive role of sFlt1 and sEng in PE. Levine et $\mathrm{al}^{29}$ also found that higher levels of serum sFlt-1 are predictive of PE. However, some studies showed the lower specificity and poor predictive value of sFlt- 1 in the early stages of pregnancy. ${ }^{38}$

\section{Inhibin A and Activin A}

These glycoproteins are produced by the fetoplacental unit. In patients who subsequently developed PE, higher serum levels of these glycoproteins are found in their first trimester. ${ }^{43}$ Hence, these can be used in prediction of PE.

\section{Pregnancy-associated Plasma Protein-A}

It is a 1,628 -amino-acid peptide. It is mainly produced by the trophoblastic cells. It has a role in cleavage of insulin-like growth factor-binding proteins. It has a role in regulation of fetal growth. Some studies have shown that plasma levels of pregnancy-associated plasma protein-A (PAPP-A) have decreased in all trimesters of pregnancy ${ }^{44}$; some other studies indicate that the levels of PAPP-A were significantly reduced in early-onset PE, while in cases of late-onset PE, the levels did not differ from the control group. ${ }^{45}$ Hence, PAPP-A is not useful in predicting late-onset $\mathrm{PE}$, and larger trials are required to confirm these preliminary predictions. ${ }^{34}$

\section{Neutrophil Gelatinase-associated Lipocalin}

Neutrophil gelatinase-associated lipocalin (NGAL) is a $25-\mathrm{kDa}$ protein and belongs to the lipocalin family. ${ }^{46,47}$ It is also known as lipocalin-2, siderocalin, uterocalin, and $24 \mathrm{p} 3 .{ }^{46,47}$ It was first identified as a matrix protein of specific granules of human neutrophils. Its expression is highly upregulated in damaged epithelial cells, during inflammation, neoplastic conditions, cardiovascular diseases, infections, and renal disorders. ${ }^{48}$ The NGAL can be detected in urine within 2 hours of kidney damage; hence, it is considered as the best and the earliest marker of acute kidney damage. ${ }^{48,49}$ In some recent studies, serum level of NGAL was found to be increased at the end of the second trimester in women who subsequently developed PE compared with the control group. ${ }^{45,47,50}$ A positive correlation of serum NGAL was found with the systolic and diastolic blood pressure and with proteinuria. ${ }^{36,45,47}$ Hence, serum NGAL can be used as a reliable biomarker for early prediction of PE.

\section{Placental Protein 13}

Placental protein 13 (PP13) is a 32-kDa dimeric protein. It was first isolated in 1983 from the syncytiotrophoblast of the placenta ${ }^{51}$ by Bohn et al. ${ }^{52}$. It was identified as a member of the galectin superfamily, which has an important role in placental implantation and remodeling of maternal arteries. ${ }^{36,53}$ To perform this function, PP13 has a carbohydrate binding domain, to which two proteins annexin II and actin-beta bind. In normal pregnancy, PP13 levels are gradually increasing, while abnormally low levels of PP13 were found in the first trimester of women who subsequently developed PE, compared with controls. ${ }^{53-55}$ Hence, it can be used as a serum biomarker for the prediction of PE. ${ }^{54}$

Nicolaides et $\mathrm{al}^{53}$ demonstrated that the combination of serum PP13 levels and uterine artery pulsating index measured by Doppler ultrasonography has a good prediction rate to identify patients with the risk of developing PE in the first trimester. The PP13-specific ELISA kits are used to measure the serum PP13 levels with good sensitivity and specificity. ${ }^{53,54}$ Hence, by using serum PP13 either alone or in combination with Doppler studies, early identification of high-risk patients can be done, and we have a good opportunity for implementation of treatment strategies. $^{53-56}$

\section{Pentraxin-related Protein 3}

Pentraxin-related protein 3 (PTX3) is a TNF-inducible gene 14 protein. This protein is encoded by the PTX3 gene in humans. ${ }^{57}$ Maternal plasma levels of PTX3 was found to be elevated in preeclamptic women in comparison to 
control group, supporting the excessive maternal inflammatory response to pregnancy as one of the etiologies of PE. ${ }^{58}$

\section{P-Selectin}

P-selectin is a protein encoded by the SELP gene in humans. ${ }^{59}$ Platelet activation in PE is reflected by elevated levels of platelets exposing P-selectin. In plasma, a noncell bound (soluble) form of P-selectin is present. Elevated levels of this soluble form have been reported in PE.

\section{Other Tests}

Laboratory tests for oxidative response, i.e., malondialdehyde, along with antioxidants have been assessed, including assays for uric acid, urinary kallikrein, fibronectin, and cytokines, but till date no test was found relevant. ${ }^{60}$ Because no single marker effectively predicts the risk of PE, in clinical practice, the current trend is to test a combination of markers. Larger studies are required to label a single molecule as a biomarker for the early prediction of $\mathrm{PE}$.

\section{CONCLUSION}

Our understanding about the etiology and pathogenesis of PE has been improved a lot in the last decade. Several studies have been done, and a lot of biomarkers were studied for prediction and diagnosis of PE, such as antiangiogenic factors like serum soluble endoglin, sFlt-1, sEng, and proangiogenic factors like VEGF and PlGF. These biomarkers have certain drawbacks like lack of high-sensitive assay kits, inability to predict onset of the disease during initial stages of gestation, low specificity, lack of prognostic value, and many other issues. Hence, further studies are required with larger population and with more precise and advanced techniques.

\section{REFERENCES}

1. Steegers EA, von Dadelszen P, Duvekot JJ, Pijnenborg R. Preeclampsia. Lancet 2010 Aug;376(9741):631-644.

2. Ghulmiyyah L, Sibai B. Maternal mortality from preeclampsia/ eclampsia. Semin Perinatol 2012 Feb;36(1):56-59.

3. Duley L. Pre-eclampsia and the hypertensive disorders of pregnancy. Br Med Bull 2003;67:161-176.

4. Report of the national high blood pressure education program working group on high blood pressure in pregnancy. Am J Obstet Gynecol 2000 Jul;183(1):S1-S22.

5. Maynard SE, Min JY, Merchan J, Lim KH, Li J, Mondal S, Libermann TA, Morgan JP, Sellke FW, Stillman IE, et al. Excess placental soluble fms-like tyrosine kinase 1 (sFlt1) may contribute to endothelial dysfunction, hypertension, and proteinuria in preeclampsia. J Clin Invest 2003 Mar;111(5):649-658.

6. Redman CW, Sacks GP, Sargent IL. Preeclampsia: an excessive maternal inflammatory response to pregnancy. Am J Obstet Gynecol 1999 Feb;180(2 Pt 1):499-506.
7. Noronha Neto C, de Souza AS, Amorim MM. Pre-eclampsia treatment according to scientific evidence. Rev Bras Ginecol Obstet 2010 Sep;32(9):459-468.

8. Arora R, Ganguli RP, Swain S, Oumachigui A, Rajaram P. Determinants of maternal mortality in eclampsia in India. Aust N Z J Obstet Gynaecol 1994;34:537-539.

9. Suhail M, Faizul Suhail M, Khan $H$. Role of vitamins $C$ and $\mathrm{E}$ in regulating antioxidant and pro-oxidant markers in preeclampsia. J Clin Biochem Nutr 2008 Nov;43(3):210-20.

10. Shah DM. Preeclampsia: new insights. Curr Opin Nephrol Hypertens 2007 May;16(3):213-220.

11. Combs CA, Katz MA, Kitzmiller JL, Brescia RJ. Experimental preeclampsia produced by chronic constriction of the lower aorta: validation with longitudinal blood pressure measurements in conscious rhesus monkeys. Am J Obstet Gynecol 1993 Jul;169(1):215-223.

12. Gervasi MT, Chaiworapongsa T, Pacora P, Naccasha N, Yoon BH, Maymon E, Romero R. Phenotypic and metabolic characteristics of monocytes and granulocytes in preeclampsia. Am J Obstet Gynecol 2001 Oct;185(4):792-797.

13. Many A, Hubel CA, Fisher SJ, Roberts JM, Zhou Y. Invasive cytotrophoblasts manifest evidence of oxidative stress in preeclampsia. Am J Pathol 2000 Jan;156(1):321-331.

14. Nielsen AH, Schauser KH, Poulsen K. Current topic: the uteroplacental renin-angiotensin system. Placenta 2000 JulAug;21(5-6):468-477.

15. Mutter WP, Karumanchi SA. Molecular mechanisms of preeclampsia. Microvasc Res 2008 Jan;75(1):1-8.

16. Redman CW, Sargent IL. Placental stress and pre-eclampsia: a revised view. Placenta 2009 Mar;30 (Suppl A):S38-S42.

17. Zhou Y, Fisher SJ, Janatpour M, Genbacev O, Dejana E, Wheelock M, Damsky CH. Human cytotrophoblasts adopt a vascular phenotype as they differentiate. A strategy for successful endovascular invasion? J Clin Invest 1997 May;99(9): 2139-2151.

18. Maynard SE, Karumanchi SA. Angiogenic factors and preeclampsia. Semin Nephrol 2011 Jan;31(1):33-46.

19. Zhou Y, Damsky CH, Fisher SJ. Preeclampsia is associated with failure of human cytotrophoblasts to mimic a vascular adhesion phenotype. One cause of defective endovascular invasion in this syndrome? J Clin Invest 1997 May;99(9): 2152-2164.

20. Staff AC, Braekke K, Johnsen GM, KarumanchiSA, Harsem NK. Circulating concentrations of soluble endoglin (CD105) in fetal and maternal serum and in amniotic fluid in preeclampsia. Am J Obstet Gynecol 2007 Aug;197(2):176.e1-171.e6.

21. Conde-Agudelo A, Villar J, Lindheimer M. World Health Organization systematic review of screening tests for preeclampsia. Obstet Gynecol 2004 Dec;104(6):1367-1391.

22. Powe CE, Levine RJ, Karumanchi SA. Preeclampsia, a disease of the maternal endothelium: the role of antiangiogenic factors and implications for later cardiovascular disease. Circulation 2011 Jun;123(24):2856-2869.

23. Tsatsaris V, Goffin F, Munaut C, BrichantJF, Pignon MR, Noel A, Schaaps JP, Cabrol D, Frankenne F, Foidart JM. Overexpression of the soluble vascular endothelial growth factor receptor in preeclamptic patients: Pathophysiological consequences. J Clin Endocrinol Metab 2003 Nov;88(11):5555-5563.

24. Venkatesha S, Toporsian M, Lam C, Hanai J, Mammoto T, Kim YM, Bdolah Y, Lim KH, Yuan HT, Libermann TA, et al. Soluble endoglin contributes to the pathogenesis of preeclampsia. Nat Med 2006 Jun;12(6):642-649. 
25. Cheifetz S, Bellón T, Calés C, Vera S, Bernabeu C, Massagué J, Letarte M. Endoglin is a component of the transforming growth factor-beta receptor system in human endothelial cells. J Biol Chem 1992 Sep;267(27):19027-19030.

26. Vailhé B, Kapp M, Dietl J, Arck P. Human first-trimester decidua vascular density: an immunohistochemical study using VE-cadherin and endoglin as endothelial cell markers. Am J Reprod Immunol 2000 Jul;44(1):9-15.

27. Raab U, Velasco B, Lastres P, Letamendía A, Calés C, Langa C, Tapia E, López-Bote JP, Páez E, Bernabéu C. Expression of normal and truncated forms of human endoglin. Biochem J 1999 May;339(Pt 3):579-588.

28. López-Casillas F, Cheifetz S, Doody J, Andres JL, Lane WS, Massagué J. Structure and expression of the membrane proteoglycan betaglycan, a component of the TGF-beta receptor system. Cell 1991 Nov;67(4):785-795.

29. Levine RJ, Lam C, Qian C, Yu KF, Maynard SE, Sachs BP, Sibai BM, Epstein FH, Romero R, Thadhani R, et al. Soluble endoglin and other circulating antiangiogenic factors in preeclampsia. N Engl J Med 2006 Sep;355(10):992-1005.

30. Robinson CJ, Johnson DD. Soluble endoglin as a secondtrimester marker for preeclampsia. Am J Obstet Gynecol 2007 Aug;197(2):174.e1-174.e5.

31. Levine RJ, Maynard SE, Qian C, Lim KH, England LJ, Yu KF, Schisterman EF, Thadhani R, Sachs BP, Epstein FH. Circulating angiogenic factors and the risk of preeclampsia. N Engl J Med 2004 Feb;350(7):672-683.

32. Agarwal I, Karumanchi SA. Preeclampsia and the antiangiogenic state. Pregnancy Hypertens 2011 Jan;1(1):17-21.

33. Romero R, Nien JK, Espinoza J, Todem D, Fu W, Chung H, Kusanovic JP, Gotsch F, Erez O, Mazaki-Tovi S. A longitudinal study of angiogenic (placental growth factor) and antiangiogenic (soluble endoglin and soluble vascular endothelial growth factor receptor-1) factors in normal pregnancy and patients destined to develop preeclampsia and deliver a small for gestational age neonate. J Matern Fetal Neonatal Med 2008 Jan;21(1):9-23.

34. Lapaire O, Shennan A, Stepan H. The preeclampsia biomarkers soluble fms-like tyrosine kinase- 1 and placental growth factor: current knowledge, clinical implications and future application. Eur J Obstet Gynecol Reprod Biol 2010 Aug;151(2):122-129.

35. Molvarec A, Ito M, Shima T, Yoneda S, Toldi G, Stenczer B, Vásárhelyi B, Rigó J Jr, Saito S. Decreased proportion of peripheral blood vascular endothelial growth factor-expressing $\mathrm{T}$ and natural killer cells in preeclampsia. Am J Obstet Gynecol 2010 Dec;203(6):567.e1-567.e8.

36. Grill S, Rusterholz C, Zanetti-Dällenbach R, Tercanli S, Holzgreve W, Hahn S, Lapaire O. Potential markers of preeclampsia - a review. Reprod Biol Endocrinol 2009 Jul;7:70-84.

37. Lam C, Lim KH, Karumanchi SA. Circulating angiogenic factors in the pathogenesis and prediction of preeclampsia. Hypertension 2005 Nov;46(5):1077-1085.

38. Hertig A, Liere P. New markers in preeclampsia. Clin Chim Acta 2010 Nov;411(21-22):1591-1595.

39. Desai J, Holt-Shore V, Torry RJ, Caudle MR, Torry DS. Signal transduction and biological function of placenta growth factor in primary human trophoblast. Biol Reprod 1999 Apr;60(4):887-892.

40. Molvarec A, Szarka A, Walentin S, Szucs E, Nagy B, Rigó J Jr. Circulating angiogenic factors determined by electrochemiluminescence immunoassay in relation to the clinical features and laboratory parameters in women with pre-eclampsia. Hypertens Res 2010 Sep;33(9):892-898.

41. Wang A, Rana S, Karumanchi SA. Preeclampsia: the role of angiogenic factors in its pathogenesis. Physiology (Bethesda) 2009;24:147-158.

42. Baumann MU, Bersinger NA, Mohaupt MG, Raio L, Gerber S, Surbek DV. First-trimester serum levels of soluble endoglin and soluble fms-like tyrosine kinase-1 as firsttrimester markers for late-onset preeclampsia. Am J Obstet Gynecol 2008 Sep;199(3):266.e1-266.e6.

43. Akolekar R, Minekawa R, Veduta A, Romero XC, Nicolaides KH. Maternal plasma inhibin A at 11-13 weeks of gestation in hypertensive disorders of pregnancy. Prenat Diagn 2009 Aug;29(8):753-760.

44. Spencer K, Cowans NJ, Nicolaides KH. Low levels of maternal serum PAPP-A in the first trimester and the risk of preeclampsia. Prenat Diagn 2008 Jan;28(1):7-10.

45. D’Anna R, Baviera G, Giordano D, Russo S, Dugo N, Santamaria A, Corrado F. First trimester serum PAPP-A and NGAL in the prediction of late-onset pre-eclampsia. Prenat Diagn 2009 Nov;29(11):1066-1068.

46. Hawkins R. New biomarkers of acute kidney injury and the cardio-renal syndrome. Korean J Lab Med 2011 Apr;31(2): 72-80.

47. Giasson J, Li GH, Chen Y. Neutrophil gelatinase-associated lipocalin (NGAL) as a new biomarker for non-acute kidney injury (AKI) diseases. Inflamm Allergy Drug Targets 2011 Aug;10(4):272-282.

48. Uttenthal LO. NGAL: a marker molecule for the distressed kidney? Clin Lab Int 2005 Nov;29:39-41.

49. Mishra J, Dent C, Tarabishi R, Mitsnefes MM, Ma Q, Kelly C, Ruff SM, Zahedi K, Shao M, Bean J. Neutrophil gelatinaseassociated lipocalin (NGAL) as a biomarker for acute renal injury after cardiac surgery. Lancet 2005 Apr;365(9466): 1231-1238.

50. D'Anna R, Baviera G, Giordano D, Todarello G, Corrado F, Buemi M. Second trimester neutrophil gelatinase-associated lipocalin as a potential prediagnostic marker of preeclampsia. Acta Obstet Gynecol Scand 2008;87(12):1370-1373.

51. Costa Fda S, Murthi P, Keogh R, Woodrow N. Early screening for preeclampsia. Rev Bras Ginecol Obstet 2011 Nov;33(11):367-375.

52. Bohn H, Kraus W, Winckler W. Purification and characterization of two new soluble placental tissue proteins (PP13 and PP17). Oncodev Biol Med 1983;4(5):343-350.

53. Nicolaides KH, Bindra R, Turan OM, Chefetz I, Sammar M, Meiri H, Tal J, Cuckle HS. A novel approach to first-trimester screening for early pre-eclampsia combining serum PP-13 and Doppler ultrasound. Ultrasound Obstet Gynecol 2006 Jan;27(1):13-17.

54. D'Anna R, Baviera G, Giordano D, Todarello G, Russo S, Recupero S, Bolignano D, Corrado F. Neutrophil gelatinaseassociated lipocalin serum evaluation through normal pregnancy and in pregnancies complicated by preeclampsia. Acta Obstet Gynecol Scand 2010;89(2):275-278.

55. Carty DM, Delles C, Dominiczak AF. Novel biomarkers for predicting preeclampsia. Trends Cardiovasc Med 2008 Jul;18(5):186-194.

56. Huppertz B, Kawaguchi R. First trimester serum markers to predict preeclampsia. Wien Med Wochenschr 2012 May;162(9-10):191-195. 
57. Breviario F, d'Aniello EM, Golay J, Peri G, Bottazzi B, Bairoch A Saccone S, Marzella R, Predazzi V, Rocchi M. Interleukin-1-inducible genes in endothelial cells. Cloning of a new gene related to C-reactive protein and serum amyloid P component. J Biol Chem 1992 Nov;267(31): 22190-22197.

58. Cetin I, Cozzi V, Papageorghiou AT, Maina V, Montanelli A, Garlanda C, Thilaganathan B. First trimester PTX3 levels in women who subsequently develop preeclampsia and fetal growth restriction. Acta Obstet Gynecol Scand 2009;88(7): 846-849.

59. Ryan US, Worthington RE. Cell-cell contact mechanisms. Curr Opin Immunol 1992 Feb;4(1):33-37.

60. Conde-Agudelo A, Villar J, Lindheimer M. World Health Organization systematic review of screening tests for preeclampsia. Obstet Gynecol 2004 Dec;104(6):1367-1391. 